AGRITECH, Vol. 37, No. 3, Agustus 2017, Hal. 312-318

DOI: http://doi.org/10.22146/agritech.11620 ISSN 0216-0455 (Print), ISSN 2527-3825 (Online)

Tersedia online di https://jurnal.ugm.ac.id/agritech/

\title{
Pengaruh Metode Kombinasi Autoklaf 2 Siklus dan Hidrolisis Asam Sitrat terhadap Sifat Kimia dan Fisika RS-3 Pati Kacang Hijau (Vigna radiata L.)
}

\author{
The Effect of Two Cycles Autoclaving and Citric Acid Hydrolysis Combination to Chemical and Physical Characteristic \\ of Mung Beans (Vigna radiata L.) Starch RS-3
}

\author{
Priyanto Triwitono*, Yustinus Marsono, Agnes Murdiati, Djagal Wiseso Marseno \\ Departemen Teknologi Pangan dan Hasil Pertanian, Fakultas Teknologi Pertanian, \\ Universitas Gadjah Mada, Jl. Flora No. 1 Bulaksumur, Yogyakarta 55281, Indonesia \\ Email: priwitono@gmail.com
}

Submisi: 14 Juni 2016; Penerimaan: 28 Juli 2016

\begin{abstract}
ABSTRAK
Kacang hijau merupakan jenis kacang-kacangan sumber amilosa yang potensial sebagai bahan dasar RS-3 rendah kalori. Kajian tentang sifat fisika dan kimiawinya membuka peluang pemanfaatannya untuk penanganan obesitas di masa datang. Telah dilakukan preparasi RS dari pati kacang hijau varietas Walet dengan perlakuan kombinasi autoklaf 2 siklus dan hidrolisis asam sitrat dan dikaji pengaruhnya terhadap sifat kimia dan fisikawinya. Hasil analisis menunjukkan bahwa perlakuan kombinasi autoklaf 2 siklus dan hidrolisis asam sitrat mampu meningkatkan kadar amilosa sebesar 20\% dan RS sebesar 47,3\%, menurunkan swelling power sebesar 47,6\%, meningkatkan WHC sebesar $237,8 \%$ dan $\mathrm{OHC}$ sebesar 9,3\%. Pengaruh lainnya yaitu mampu menurunkan derajat putih warna pati dengan $\Delta \mathrm{E}$ sebesar 32,6, menurunkan viskositas dengan viskositas balik $710 \mathrm{Cp}$. Tipe kurva amilografi berubah dari tipe $\mathrm{C}$ ke tipe $\mathrm{D}$, bentuk granula tidak beraturan, ukuran granula meningkat tiga kali lipat, dan pola difraksinya tidak berubah (tetap tipe C) tetapi intensitasnya meningkat.
\end{abstract}

Kata kunci: Amilosa; autoklaf; obesitas; asam sitrat; kacang hijau; RS; pati

\begin{abstract}
Mung beans are potential sources of amylose as ingredients low-calorie RS-3. Studies on physical and chemical properties are most important for the obesity treatment in the future. Preparation method of RS-3 using a combination treatment of 2 cycles autoclaving and citric acid hydrolysis on mung bean starch of Walet varieties and the effect on chemical and physical properties were conducted. The result showed that the preparation method improved amylose content by $20 \%$ and RS by $47.3 \%$, decrease the swelling power by $47.6 \%$, increase in the WHC by $237.8 \%$ and OHC by $9.3 \%$. The starch color also become brighter with the $\Delta \mathrm{E} 32.6$. Its viscosity became lower with a setback of 710 $\mathrm{Cp}$. The amilograph curve type changed from type $\mathrm{C}$ to $\mathrm{D}$. The granule shape become irregular and the size increase three-fold. The diffraction pattern has steady in type $\mathrm{C}$ but the intensity increased.
\end{abstract}

Keywords: Amylose; autoclave; obesity; citric acid; mung bean; RS; starch 


\section{PENDAHULUAN}

Kacang hijau (Vigna radiata) merupakan kacangkacangan sumber amilosa yang sangat potensial. Kacang hijau mengandung amilosa 31,1 hingga 41,82 \% (bk) (Chang dkk., 2006; Wenhao-Li dkk., 2011). Triwitono dkk. (2016) melaporkan bahwa kacang hijau varietas Walet mempunyai kadar amilosa paling tinggi diantara varietas lainnya yaitu $55,39 \%$ (bk), sehingga potensial sebagai bahan dasar RS yang baik bagi kesehatan (Stipanuk, 2000). Kadar amilosa yang tinggi berpotensi menghasilkan RS-3 yang tinggi pula (Sievert dan Pomeranz, 1989).

RS-3 adalah salah satu tipe RS yang terbentuk karena perlakuan hidrotermal pati dan retrogradasi setelah pendinginan. Selama retrogradasi, terjadi reasosiasi molekul pati membentuk struktur kompleks yang stabil terhadap panas dan juga tahan terhadap hidrolisis enzim amilase (Jane dan Robyt, 1984). Terbentuknya RS tersebut dipengaruhi oleh beberapa faktor, antara lain kadar amilosa, rasio amilosa amilopektin, kadar air, tingkat gelatinisasi, perlakuan termal, pendinginan, penyimpanan, lama dan suhu penyimpanan gel pati, banyaknya siklus autoklaf dan pendinginan, serta adanya lipida dan protein (Gidley dkk., 1995; Kale dkk., 2002; Sievert dan Pomeranz, 1989).

Beberapa penelitian melaporkan bahwa banyaknya siklus autoklaf-pendinginan mampu meningkatkan kadar RS-3 secara signifikan. Perlakuan tiga kali siklus autoklafpendinginan mampu meningkatkan RS dari 4,18\% (bk), $1,86 \%$ (bk), dan 1,51\% (bk) pada legume, serealia, dan umbiumbian menjadi 8,16\% (bk), 3,25\% (bk), dan 2,51\% (bk) (Yadav dkk., 2009). Perlakuan autoklaf-pendinginan dengan 1 - 4 siklus pada pati jagung beramilosa tinggi (High Amylose Corn Starch) dengan kadar amylosa 70\% (bk) menghasilkan kadar RS-3 berturut-turut sebesar 27,2\%; 29,7\%; 30,7\%, dan 30,7\% (Zhao dan Lin, 2009). Perlakuan autoklafpendinginan dengan 1 - 5 siklus pada pati gandum mampu meningkatkan RS-3 dari 0,46\% (bk) menjadi 4,35\% hingga 11,95\% (Ranhotra dkk., 1991). Penggunaan siklus autoklafpendinginan 1-2 kali saja dinilai telah mampu meningkatkan RS-3 cukup signifikan (Zhao dan Lin, 2009).

Zhao dan Lin (2009) juga melaporkan bahwa hidrolisis asam sitrat $0,1 \mathrm{~mol} / \mathrm{L}$ selama 12 jam pada suhu kamar terhadap retrogradasi pati jagung beramilosa tinggi (High Amylose Corn Starch) mampu meningkatkan hasil RS-3 secara signifikan dari 29,7\% menjadi 39\%. Asam Sitrat merupakan asam organik lemah dan pada konsentrasi rendah diduga dapat menghidrolisis rantai percabangan amilopektin pati jagung beramilosa tinggi yang teretrogradasi menghasilkan polimer glukosa rantai lurus yang lebih kecil sehingga berkontribusi meningkatkan kandungan RS-3.
Kajian sifat-sifat pati kacang hijau dari berbagai negara sudah cukup banyak dilakukan, namun masih terbatas pada sifat fisik, sifat kimiawi, sifat termal dan sifat morfologinya (Wenhao Li dkk., 2011; Li dkk., 2011; Liu dan Shen, 2007a; Liu dan Shen, 2007b). Penelitian tentang sifat-sifat RS dari pati kacang hijau asal Indonesia dan sifat fungsionalnya sejauh ini belum dilakukan, sehingga menarik untuk dikaji lebih jauh terutama untuk aplikasi penanganan obesitas nantinya.

\section{METODE PENELITIAN}

\section{Bahan}

Bahan yang digunakan adalah kacang hijau varietas Walet yang diperoleh dari Balitkabi Malang, Indonesia dan bahan-bahan kimia pro-analisis $(\mathrm{NaOH}, \mathrm{HCl})$.

\section{Peralatan}

Peralatan penelitian yang digunakan antara lain blender, cabinet dryer, ayakan 80 mesh, alat-alat gelas, oven, neraca analitis, Chromameter Minolta, spektrofotometer UV-Vis, Scanning Electron Microscope (SEM), X-Ray Diffraction (XRD) dan Rapid Visco Analyzer (RVA).

\section{Cara Penelitian}

Pati kacang hijau diekstraksi dengan metode Hoover dkk. (1997) yang dimodifikasi (Triwitono dkk., 2016), selanjutnya dilakukan preparasi RS-3 menggunakan perlakuan kombinasi 2 siklus Autoklaf-pendinginan dan hidrolisis asam sitrat (Zhao dan Lin, 2009). Disiapkan suspensi pati $20 \%$, kemudian diautoklaf pada suhu 121 ${ }^{\circ} \mathrm{C} / 20$ menit dan dilanjutkan dengan pendinginan pada suhu $4{ }^{\circ} \mathrm{C} / 24$ jam. Siklus kombinasi autoklaf dan pendinginan ini diulang sekali lagi, selanjutnya dilakukan hidrolisis asam sitrat pada konsentrasi $0,1 \mathrm{M}$ pada suhu kamar selama 12 jam, dinetralkan dengan $\mathrm{NaOH} 1 \mathrm{M}(\mathrm{pH} 7,0)$ kemudian disimpan pada suhu $4{ }^{\circ} \mathrm{C} / 24$ jam. Selanjutnya RS 3 yang diperoleh dioven pada suhu $105^{\circ} \mathrm{C}$, ditepungkan, dan dianalisis sifat kimia maupun sifat fisikanya.

\section{Metode Analisis}

Analisis sifat kimia meliputi kadar Amilosa (metode Juliano, 1971) dan Kadar Resistant Starch/RS (Goni dkk., 1996). Analisis sifat fisik meliputi Water Holding Capacity/ WHC (Yamazaki, 1953); Oil Holding Capacity/OHC (Yeh dkk., 2005); Swelling Power (metode Takashi dan Sieb, 1988); Warna (Chromameter, Hunter System); Sifat Pasta / Rheology (Rapid Visco Analyzer); Perubahan Struktur Pati (SEM/Scanning Electron Microscope); Sifat Kristalinitas Granula Pati (XRD - X Ray Diffraction). 


\section{HASIL DAN PEMBAHASAN}

\section{Sifat Kimia RS-3 Pati Kacang Hijau Varietas Walet}

Tabel 1. Kadar RS dan amilosa dari RS-3 pati kacang hijau varietas Walet dengan kombinasi autoklaf 2 siklus dan hidrolisis asam sitrat

\begin{tabular}{lcc}
\hline \multicolumn{1}{c}{ Sampel } & $\begin{array}{c}\text { Resistant starch } \\
(\mathrm{RS}), \% \text { bk }\end{array}$ & $\begin{array}{c}\text { Amilosa, } \\
\% \mathrm{bk}\end{array}$ \\
\hline $\begin{array}{l}\left.\text { Pati alami }{ }^{*}\right) \\
\text { RS-3 kombinasi autoklaf } 2\end{array}$ & $10,58^{\mathbf{a}}$ & $55,39^{\mathrm{a}}$ \\
$\begin{array}{l}\text { siklus dan hidrolisis asam } \\
\text { sitrat }\end{array}$ & $15,58^{\mathbf{b}}$ & $66,47^{\mathbf{b}}$ \\
\hline
\end{tabular}

Superscript yang berbeda dalam satu kolom menunjukkan ada perbedaan signifikan $(p<0,05)$.

*) Triwitono dkk. (2016).

Kombinasi autoklaf 2 siklus dan hidrolisis asam sitrat mampu meningkatkan kadar RS secara nyata sebesar 47,3\% maupun amilosa sebesar 20\% (Tabel 1). Peningkatan kadar amilosa akibat perlakuan HMT (Heat Moisture Treatment) dilaporkan oleh Li dkk. (2011) dan Surendra dan Parimalavalli (2013). Peningkatan kadar RS akibat perlakuan autoklaf juga dilaporkan oleh Dundar dan Gocmen (2013). Pemanasan bertekanan dan hidrolisis asam sitrat diduga menyebabkan pemotongan rantai percabangan amilopektin menjadi amilodekstrin rantai lurus dengan panjang rantai lebih pendek dan berat molekul lebih kecil yang berkontribusi terhadap peningkatan kadar amilosa maupun kadar RS-3 (Ozturk dkk., 2011).

Meskipun dalam preparasi RS ini menggunakan asam sitrat, dapat dipastikan bahwa RS yang dihasilkan bukan RS-4 atau pati sitrat, sebab metodenya sangat berbeda. Pada metode preparasi pati sitrat, konsentrasi yang digunakan jauh lebih pekat $(40 \%)$ dan terdapat proses pemanasan pada suhu $140{ }^{\circ} \mathrm{C}$ selama 1-5 jam untuk proses esterifikasi. Asam sitrat bila dipanaskan akan terbentuk asam sitrat anhidrat, dan bila bereaksi dengan pati akan mengalami esterifikasi membentuk pati sitrat atau RS-4 (Mei dkk., 2015). Pada metode preparasi RS ini hanya menggunakan asam sitrat konsentrasi rendah 0,1 molar/L dan tidak ada proses pemanasan, sehingga tidak terbentuk pati sitrat. Oleh karena itu peran asam sitrat adalah untuk proses hidrolisis memecah rantai percabangan amilopektin menjadi amilodekstrin rantai lurus yang diharapkan berkontribusi terhadap peningkatan kadar amilosa maupun RS.

\section{Sifat Fisika RS-3 Pati Kacang Hijau Varietas Walet}

Hasil analisis sifat fisika RS-3 yang meliputi Sifat Swelling Power (SP), Water Holding Capacity (WHC)
Tabel 2. Sifat fisika dari RS-3 pati kacang hijau varietas Walet dengan kombinasi autoklaf 2 siklus dan hidrolisis asam sitrat

\begin{tabular}{lccc}
\hline \multicolumn{1}{c}{ Sampel } & SP, g/g & WHC, \% & OHC, \% \\
\hline $\begin{array}{l}\text { Pati alami *) } \\
\text { RS-3 kombinasi }\end{array}$ & $17,11^{\mathrm{a}}$ & $65,26^{\mathrm{a}}$ & $59,36^{\mathrm{a}}$ \\
$\begin{array}{l}\text { autoklaf 2 siklus dan } \\
\text { hidrolisis asam Sitrat }\end{array}$ & $9,99^{\mathrm{b}}$ & $220,47 \mathrm{~b}^{\mathrm{b}}$ & $64,89^{\mathrm{b}}$ \\
\hline
\end{tabular}

Superscript yang berbeda dalam satu kolom menunjukkan ada perbedaan signifikan $(p<0,05)$.

*) Triwitono dkk. (2016).

dan Oil Holding Capacity (OHC) disajikan pada Tabel 2. Swelling power (SP) adalah kemampuan pembengkakan setelah pati menyerap air dan mengalami gelatinisasi. WHC (kemampuan menahan air) dan OHC (kemampuan menahan minyak) adalah kemampuan pati menyerap dan menahan air atau minyak setelah pati berinteraksi dengan air atau minyak. Pati alami yang belum mengalami gelatinisasi atau proses pemanasan, mempunyai kemampuan pembengkakan atau SP yang cukup besar.

Menurut Singh dkk. (2006), kemampuan pembengkakan pati dipengaruhi oleh kadar amilosa. Semakin tinggi kadar amilosa, gugus hidroksil dan hidrofil yang dikandung juga makin tinggi, sehingga makin banyak air yang terikat, proses gelatinisasi makin sempurna dan swelling powernya makin besar. Namun setelah mengalami perlakuan (kombinasi autoklaf 2 siklus dan hidrolisis asam sitrat) terjadi penurunan SP yang signifikan dan peningkatan WHC maupun $\mathrm{OHC}$ yang signifikan pula. Penurunan SP diduga berhubungan erat dengan terjadinya retrogradasi selama pembentukan RS-3. Perubahan struktur granula akibat retrogradasi pati menjadi lebih keras (stabilitas kristalnya meningkat) mengakibatkan penetrasi air kedalam struktur pati terhambat atau terbatas (Miao dkk., 2009), sehingga proses gelatinisasi tidak sempurna atau terbatas dan mengakibatkan SP menurun.

Proses pemanasan bertekanan dan hidrolisis asam sitrat) menyebabkan pemotongan rantai percabangan amilopektin menjadi amilodekstrin rantai lurus dengan panjang rantai lebih pendek, berat molekul lebih kecil (Ozturk dkk., 2011) dan gugus hidroksil lebih banyak, sehingga lebih mudah menyerap air dan mempunyai kemampuan WHC jauh lebih besar daripada pati alami. Pemendekan molekul pati secara tidak langsung juga meningkatkan luas permukaannya, sehingga kemampuan interaksi dengan minyak (OHC) mengalami peningkatan meskipun peningkatannya sangat terbatas karena minyak bersifat hidrofob (sulit bereaksi dengan air). Dalam hal ini minyak diduga hanya menyelimuti disekitar RS-3 saja. 


\section{Warna}

Kombinasi autoklaf 2 siklus dan hidrolisis asam sitrat berpengaruh nyata terhadap penurunan derajat putih warna pati kacang hijau varietas Walet (Tabel 3). Pati alami mempunyai warna putih dengan derajat putih tertentu. Preparasi RS dengan kombinasi autoklaf 2 siklus dan hidrolisis asam sitrat menyebabkan penurunan kecerahan atau derajat putihnya (Lightness). Penurunan derajat putih tersebut kemungkinan disebabkan oleh oksidasi selama preparasi RS yang melibatkan pemanasan, yaitu pada saat pemanasan autoklaf 2 siklus dan pengeringan sebelum penepungan.

Secara keseluruhan penurunan derajat putih tersebut mempunyai perbedaan warna $\Delta \mathrm{E}$ sebesar 32,6 (artinya warna dipersepsikan serupa). Delta E merupakan parameter untuk menunjukkan perbedaan dua warna suatu sampel dengan warna standart. Delta E mempunyai skala nilai 0 - 100 yang masing-masing mempunyai arti atau persepsi tertentu. Nilai $\Delta \mathrm{E} \geq 1$ artinya tidak dapat dipersepsikan oleh mata manusia, $\Delta \mathrm{E} 1-2=$ warna baru jelas bila dengan pengamatan dekat, $\Delta \mathrm{E}>2-10=$ sekilas pandang warna nampak jelas, $\Delta \mathrm{E} 11-49$ = warna serupa/sangat mirip dengan warna sebaliknya, $\Delta \mathrm{E}$ 100 = warna bertolak belakang (Zschuessler, 2016).

Tabel 3. Warna RS-3 pati kacang hijau varietas Walet dengan kombinasi autoklaf 2 siklus dan hidrolisis asam sitrat

\begin{tabular}{lcccc}
\hline \multicolumn{1}{c}{ Sampel } & $\mathrm{L}$ & $\mathrm{a}$ & $\mathrm{b}$ & $\Delta \mathrm{E}$ \\
\hline Pati alami $^{*}$ ) & $88,09^{\mathrm{a}}$ & $-0,69^{\mathrm{a}}$ & $1,99^{\mathrm{a}}$ & - \\
\hline $\begin{array}{l}\text { RS-3 kombinasi autoklaf 2 siklus } \\
\text { dan hidrolisis asam sitrat }\end{array}$ & $85,83^{\mathrm{b}}$ & $0,19^{\mathrm{b}}$ & $7,16^{\mathrm{b}}$ & 32,6 \\
\hline
\end{tabular}

$\mathrm{L}=$ Derajat putih $; \mathrm{a}=$ Nilai merah-hijau $; \mathrm{b}=$ Nilai Kuning $-\mathrm{Biru} ; \Delta \mathrm{E}=$ perbedaan warna

$\Delta \mathrm{E}=\sqrt{(L 2-L 1) 2+(a 2-a 1) 2+(b 2-b 1) 2}$

Superscript yang berbeda dalam satu kolom menunjukkan ada perbedaan signifikan $(p<0,05)$.

*) Triwitono dkk. (2016).

\section{Sifat Viskoamilografi}

Perilaku sifat amylografi RS pati kacang hijau varietas Walet dengan metode kombinasi autoklaf 2 siklus dan hidrolisis asam sitrat dapat dilihat pada Tabel 4 dan Gambar 1. Kombinasi autoklaf 2 siklus dan hidrolisis asam sitrat berpengaruh terhadap perubahan tipe kurva amilografi dan viskostas balik.

Kombinasi autoklaf 2 siklus dan hidrolisis asam sitrat menyebabkan perubahan tipe kurva amilografi dari tipe $\mathrm{C}$ menjadi tipe D. Pati alami mempunyai tipe kurva amilografi $\mathrm{C}$ (menunjukkan viskositas sangat tinggi yang konstan atau naik saat pemasakan), sedangkan RS kombinasi autoklaf 2 siklus dan hidrolisis asam sitrat mempunyai kurva amilografi tipe D (ketika dipanaskan tidak membengkak cukup untuk menghasilkan pasta kental). Pati tipe D mempunyai kemampuan pembengkakan tinggi, sedangkan pati tipe $\mathrm{C}$ mempunyai kemampuan pembengkakan sangat terbatas karena struktur internal granulanya kaku (Schoch dan Maywald, 1968). Kombinasi autoklaf 2 siklus dan hidrolisis asam sitrat menyebabkan penurunan viskositas balik dari $1430 \mathrm{Cp}$ menjadi $710 \mathrm{Cp}$. Viskositas balik yang rendah ini menunjukkan RS kombinasi autoklaf 2 siklus dan hidrolisis asam sitrat lebih cepat teretrogradasi daripada pati alami.

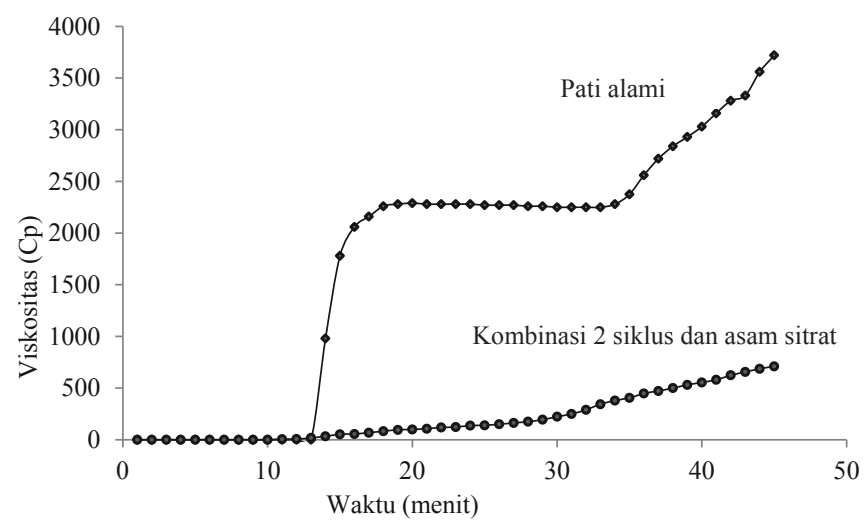

Gambar 1. Pola amylografi pati alami dan RS-3 pati kacang hijau varietas Walet dengan kombinasi autoklaf 2 siklus dan hidrolisis asam sitrat

Tabel 4. Sifat viskoamilografi RS-3 pati kacang hijau varietas Walet dengan kombinasi autoklaf 2 siklus dan hidrolisis asam sitrat

\begin{tabular}{cccccccc}
\hline \multirow{2}{*}{ Metode preparasi RS } & \multicolumn{2}{c}{ Awal gelatinisasi } & \multicolumn{3}{c}{ Granula pati pecah } & \multicolumn{2}{c}{ Viskositas } \\
\cline { 2 - 7 } & Waktu (menit) & Suhu $\left({ }^{\circ} \mathrm{C}\right)$ & Waktu (menit) & Suhu $\left({ }^{\circ} \mathrm{C}\right)$ & Viskositas & $50{ }^{\circ} \mathrm{C}(\mathrm{Cp})$ & Balik $(\mathrm{Cp})$ \\
\hline 14 & 78,7 & 20 & 94,2 & 2290 & 3721 & 1430 \\
& 13 & 77,0 & - & - & - & 710 & 710 \\
\hline
\end{tabular}

*) Triwitono dkk. (2016) 


\section{Perubahan Bentuk dan Ukuran Granula}

Hasil pengamatan dengan SEM (Scanning Electron Microscope) menunjukkan bahwa kombinasi 2 siklus dan hidrolisis asam sitrat berpengaruh terhadap bentuk dan ukuran granula pati (gambar 2). Granula pati alami berbentuk oval sampai bulat seperti ginjal, sedangkan RS dengan preparasi kombinasi autoklaf 2 siklus dan hidrolisis asam sitrat mempunyai bentuk tidak beraturan. Perubahan struktur ini disebabkan karena granula pati telah mengalami gelatinisasi dan pecah selama proses pemanasan bertekanan dengan autoklaf dan selanjutnya mengalami retrogradasi selama pendinginan. Selain terjadi perubahan bentuk, perlakuan kombinasi 2 siklus dan hidrolisis asam sitrat juga menyebabkan perubahan ukuran menjadi sekitar tiga kali lipat dari ukuran granula pati mula-mula.

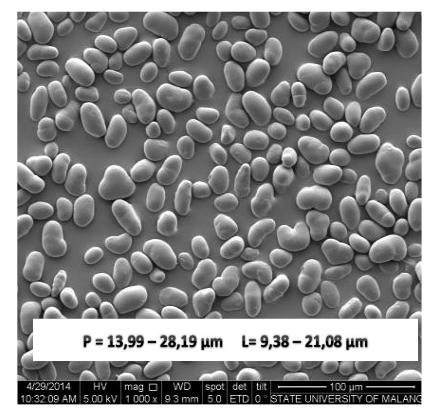

Gambar 2. Bentuk dan ukuran granula (a) pati alami (Triwitono dkk., 2016)

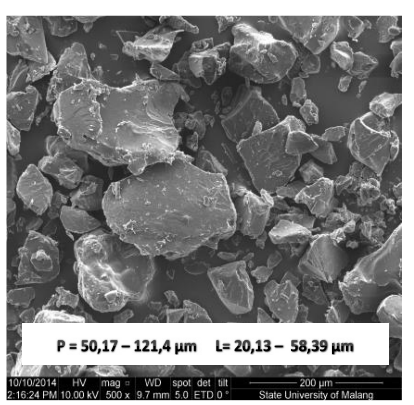

(b) (perbesaran $1000 \mathrm{X}$ ) dan (b) RS-3 kombinasi autoklaf 2 siklus dan hidrolisis asam sitrat (perbesaran $500 \mathrm{X}$ )

\section{Pola Difraksi Sinar X (X-Ray Diffraction)}

Pengujian pola spectrum difraksi sinar X (X-Ray Diffraction) dimaksudkan untuk mengetahui type kristalinitas dari pati. Pati merupakan bahan semikristalin, yaitu butiran yang mengandung daerah kristal dan amorf. Daerah kristalin sebagian besar terdiri dari polimer amilopektin, sedangkan daerah amorf granula pati terdiri dari amilosa dan titik percabangan amilopektin (Ratnayake dan Jackson, 2006). Spektrum pola difraksi sinar X RS-3 pati kacang hijau varietas Walet disajikan pada Gambar 3.

Berdasarkan karakteristik pola difraksinya (Cai dan We, 2013) pati alami dan RS dengan perlakuan Kombinasi Autoklaf 2 siklus dan Hidrolisis asam sitrat mempunyai pola spektrum difraksi sinar X yang serupa, yaitu tipe C. Semua pola difraksinya mempunyai puncak terkuat pada sudut difraksi (20) $15^{\circ}, 17^{\circ}$, dan $23^{\circ}$.

Meskipun pola difraksinya sama, tetapi spektrum difraksi sinar X intensitasnya berbeda. RS kombinasi autoklaf 2 siklus dan hidrolisis sitrat mempunyai intensitas sinar $\mathrm{X}$ lebih tinggi daripada pati alami. Menurut Reddy dkk. (2013), intensitas spektrum difraksi sinar X dipengaruhi oleh terjadinya rekristalisasi dan retrogradasi yang merubah

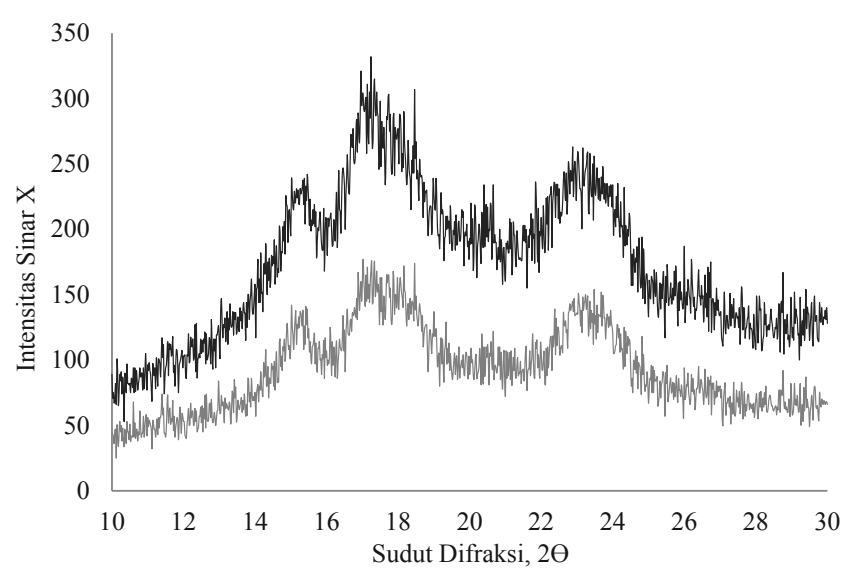

Gambar 3. Pola difraksi sinar X RS-3 pati kacang hijau varietas Walet kombinasi autoklaf 2 siklus dan hidrolisis asam sitrat

strukturnya menjadi lebih keras. Itulah sebabnya mengapa perlakuan RS kombinasi autoklaf 2 siklus dan hidrolisis sitrat yang menghasilkan RS-3 lebih tinggi (15,58\% bk) daripada RS pati alami $(10,58 \%$ bk) menunjukkan intensitas sinar $\mathrm{X}$ yang lebih tinggi pula.

\section{KESIMPULAN}

Kombinasi Autoklaf-Pendinginan dan Hidrolis Asam Sitrat menyebabkan perubahan sifat kimia dan fisika RS-3 yang dihasilkan, yaitu kadar amilosa meningkat sebesar 20\%, kadar RS meningkat sebesar 47,3\%, swelling power menurun sebesar 47,6\%, WHC meningkat sebesar 237,8\% dan $\mathrm{OHC}$ sebesar 9,3\%. Pengaruh lainnya yaitu menurunkan derajat putih warna pati dengan $\Delta \mathrm{E}$ sebesar 32,6, menurunkan viskositas dengan viskositas balik $710 \mathrm{Cp}$ dan tipe kurva amilografi berubah dari tipe $\mathrm{C}$ ke tipe $\mathrm{D}$, bentuk granula menjadi tidak beraturan dan ukuran granula meningkat tiga kali lipat, serta pola difraksinya tidak berubah (tipe C) tetapi intensitasnya meningkat.

\section{DAFTAR PUSTAKA}

Cai, C.H. dan Wei, C.X. (2013). In situ observation of crystallinity disruption patterns during starch gelatinization. Carbohydrate Polymers 92: 469-478.

Chang, Y.H., Lin C.L. dan Chen, J.C. (2006). Characteristics of mung bean starch isolated by using lactic acid fermentation solution as the steeping liquor. Original Research Article. Food Chemistry 99: 794-802.

Dundar, A.N. dan Gocmen, D. (2013). Effects of autoclaving temperature and storing time on resistant starch 
formation and its functional and physicochemical properties. Carbohydrate Polymers 97: 764-771.

Gidley, M.J., Cooke, O., Darks, A.H., Hoffmann, R.A., Russel, A.L. dan Greenwell, P. (1995). Molecular order and structure in enzyme resistant retrograded starch. Carbohydrate Polymers 28: 23-31.

Goñi, I., García-Diz, L., Mañas, E., Saura-Calixto, F. (1996). Analysis of resistant starch: a method for foods and food products. Food Chemistry 56: 445-449.

Hoover, R., Li, Y.X., Hynes, G., Senanayake, N. (1997). Physicochemical characterization of mung bean starch. Food Hydrocolloids 11: 401-408.

Jane, J.L. dan Robyt, J.F. (1984). Structure studies of amylose- $\mathrm{V}$ complexes and retrograded amylose by action of alpha amylases and a new method for preparing amylodextrins. Carbohydrate Research 132: 105-118.

Juliano, B.O (1971). A simplified assay for milled rice amylose. Cereal Science Today 16: 334-340.

Kale, C.K., Kotecha, P.M., Chavan, J.K. dan Kadam, S.S. (2002). Effect of processing conditions of bakery products on formation of resistant starch. Journal Food Science Technology 5: 520-524.

Liu, W. dan Shen, Q. (2007a). Structure analysis of mung bean starch from sour liquid processing and centrifugation. Journal of Food Engineering 79(4): 1310-1314.

Liu, W. dan Shen, Q. (2007b). Studies on the physicochemical properties of mung bean starch from sour liquid processing and centrifugation. Journal of Food Engineering 79(1): 358-363.

Mei, Ji-Qiang., Zhou, Da-Nian, Jin, Zheng-Yu, Xu, XueMing dan Chen, Han-Qing (2015). Effects of citric acid esterification on digestibility, structural and physicochemical properties of cassava starch. Food Chemistry 187: 378-384.

Miao, M., Jiang, B. dan Zhang, T. (2009). Effect of pullulanase debranching and recrystallization on structure and digestibility of waxy maize starch. Carbohydrate Polymers 76(2): 214-221.

Ozturk, S., Koksel, H. dan Ng, P.K.W. (2011). Production of resistant starch from acid-modified amylotype starches with enhanced functional properties. Journal of Food Engineering 103: 156-164.

Ranhotra, G.S., Gelroth, K.J.A., Astroth, K. dan Eisenbraun, G.J. (1991). Effect of resistant starch on intestinal responses in rats. Journal of Cereal Chemistry 68(2): $130-132$.
Ratnayake, W.S. dan Jackson, D.S. (2006). Gelatinization and solubility of corn starch during heating in excess water: new insights. Journal of Agricultural and Food Chemistry 54: 3712-3716.

Reddy, C.K., Suriya, M. dan Haripriya, S. (2013). Physicochemical and functional properties of resistant starch prepared from red kidney beans (Phaseolus vulgaris L) starch by enzymatic method. Carbohydrate Polymers 95: $220-226$.

Sajilata, M.G., Singhal, R.S. dan Kulkarni, P.R. (2006). Resistant starch - a review. Comprehensive Reviews in Food Science and Food Safety 5: 1-17.

Schoch, T.J. dan Maywald, E.C. (1968). Preparation and properties of various legume starches. Cereal Chemistry 45: $564-573$.

Sievert, D. dan Pomeranz, Y. (1989). Enzyme-resistant starch I. characterization and evaluation by enzymatic, thermoanalytical, and microscopic methods. Cereal Chemistry 66: 342-347.

Stipanuk, M.H. (2000). Biochemical and Physiological Aspect of Human Nutrition. W.B. Saunders Companny, Toronto.

Li, S., Ward, R. dan Gao, Q. (2011). Effect of heatmoisture treatment on the formation and physicochemical properties of resistant starch from mung bean (Phaseolus radiatus) starch. Food Hydrocolloids 25(7): 1702-1709.

Surendra, A.B. dan Parimalavalli, R. (2013). Effect of autoclaving on functional, chemical, pasting and morphological properties of sweet potato starch. Journal of Root Crops 39(1): 78-83.

Takashi, S. dan Seib, P.A. (1988): Paste and gel properties of prime corn and wheat starches with and without native lipids. Journal of Cereal Chemistry 65: 474-480.

Triwitono, P., Marsono, Y., Murdiati, A. dan Marsena, D.W. (2016). Isolasi dan karakterisasi sifat pati kacang hijau (Vigna radiata L.) beberapa varietas lokal Indonesia. Agritech 37(2): 192-198.

Wenhao-Li, Shu, C., Zhang, P. dan Shen, Q. (2011). Properties of starch separated from ten mung bean varieties and seeds processing characteristics. Food Bioprocess Technology 4: 814-821.

Yadav, B.S., Sharma, A. dan Yadav, R.B. (2009). Studies on effect of multiple heating/cooling cycles on the resistant starch formation in cereals, legumses and tubers. International Journal of Food Sciences and Nutrition 60(S4):258-272. 
Yamazaki, W.T. (1953). An alkaline water retention capacity test for the evaluation of cookie baking potentialities of soft winter wheat flours. Cereal Chemistry 30: 242-246.

Yeh, H.Y., Su, N.W. dan Lee, M.H. (2005). Chemical compositions and physicochemical properties of the fiber-rich materials prepared from shoyu mash residue. Journal of Agriculture and Food Chemistry 53: 43614366.
Zhao, X.H. dan Lin, Y. (2009). The impact of coupled acid or pullulanase debranching on the formation of resistant starch from maize starch with autoclaving-cooling cycles. European Food Research Technology 230: 179184.

Zschuessler (2016). Delta E 101. http://zschuessler.github.io/ DeltaE/learn/. [14 April 2016]. 